\title{
Evidence for the action of bovine follicular fluid factor(s) other than inhibin in suppressing follicular development and delaying oestrus in heifers
}

\author{
A. S. Law ${ }^{1}$, G. Baxter ${ }^{1}$, D. N. Logue ${ }^{2}$, T. O'Shea ${ }^{3}$ and R. Webb ${ }^{1}$ \\ ${ }^{\prime}$ AFRC Institute of Animal Physiology and Genetics Research, Edinburgh Research Station, \\ Roslin, Midlothian, EH25 9PS, UK, ${ }^{2}$ Scottish Agricultural College, Dairy Herd Health Unit, \\ Auchincruive, Ayr, KA6 5HW, UK, and ${ }^{3}$ Department of Physiology, University of New England, \\ Armidale, NSW 2351, Australia
}

Summary. The aim of this study was to investigate the importance of inhibin in the delay in return to oestrus in heifers induced by steroid-stripped bovine follicular fluid (bFF). Oestrous activity was synchronized in 18 Hereford $\times$ Friesian heifers with two injections of prostaglandin (PG) 12 days apart. At the time of the second PG injection (time 0), the animals were assigned at random to one of three experimental groups and received i.v. injections of $20 \mathrm{ml}$ saline (controls, $n=6$ ), whole bFF (FF group, $n=6$ ) or bFF in which the bioactive inhibin content had been reduced by $>95 \%$ by immunoaffinity chromatography (-INH group, $n=6$; inhibin content $\approx 0.8 \mathrm{ml}$ whole $\mathrm{bFF}$ ) every $8 \mathrm{~h}$ for 2 days. In a dose-response study, $2.5 \mathrm{ml}$ whole bFF was insufficient to delay oestrus consistently following a similar synchronization regimen. Blood samples were taken every $8 \mathrm{~h}$, initially before each injection and then subsequently for a further 9 days for hormone analysis. Animals were observed every $8 \mathrm{~h}$ throughout the experiment for signs of behavioural oestrus. The ovaries of all animals were examined using real-time ultrasonography about $30 \mathrm{~h}$ after the second $P G$ injection.

Treatment failed to suppress peripheral follicle-stimulating hormone (FSH) concentrations, although a significant increase was observed in both treatment groups after cessation of injections. Progesterone concentrations fell immediately after the second PG injection in all animals and remained below minimum detectable concentrations in all treated animals for the remainder of the experiment. In control animals, progesterone rose above minimum detectable concentrations by day 6 and continued to rise until the end of the experiment. Analysis of samples taken from treated animals several days after observed oestrus revealed that all had apparently ovulated. Mean daily luteinizing hormone ( $\mathrm{LH}$ ) concentrations did not differ between treatment groups before ovulation, but after ovulation, mean daily LH was significantly reduced in control animals as progesterone concentrations rose.

Follicular development, as assessed by the mean antral diameter of the largest follicle on a pair of ovaries at ultrasound examination, was significantly suppressed in treated animals compared with controls $(P<0.01)$ and there was no significant difference $(P=0 \cdot 397)$ between the two treatment groups. Control animals displayed oestrus $68 \mathrm{~h}$ ( $\pm 8 \mathrm{SEM}$ ) after the second PG injection, but oestrus was delayed in treated animals to $186 \mathrm{~h} \pm 5$ (FF group) and $191 \mathrm{~h} \pm 6$ (-INH group).

We conclude that the suppression of follicular development and the subsequent delay in return to oestrus associated with bFF treatment of cattle is not due to inhibin. 
Furthermore, the data suggest that the rebound of FSH concentrations following bFF treatment is similarly due to a factor other than inhibin.

Keywords: inhibin; bovine follicular fluid; FSH; oestradiol; oestrus; cattle

\section{Introduction}

The administration of steroid-free bovine follicular fluid (bFF) to cattle or sheep at about the time of progesterone withdrawal results in a marked increase in the length of time to the return of oestrus owing to a suppression of follicular development (Miller et al., 1979, 1982; McNeilly, 1984, 1985; Johnson \& Smith, 1985; Wallace \& McNeilly, 1985, 1986; Henderson et al., 1986; Quirk \& Fortune, 1986). In sheep, this follicular suppression is associated with, and has been attributed to, a decrease in peripheral concentrations of follicle-stimulating hormone (FSH) (Miller et al., 1982; McNeilly, 1984; Henderson et al., 1986; Wallace \& McNeilly, 1986; Hunter et al., 1988). As the majority of the FSH-suppressing activity in steroid-stripped bFF is due to its inhibin content (Muttukrishna \& Knight, 1990), this delay in return to oestrus has been assumed to be due to the indirect action of inhibin on follicular growth. However, in intact cattle, Johnson \& Smith (1985) could not demonstrate a suppression of FSH, in spite of a distinct delay in oestrus. Using smaller groups of animals, Quirk \& Fortune (1986) suggested that reduced FSH was the reason for the delay in return to oestrus, but the changes in FSH seen during treatment were the same in both control and bFF-treated animals. Price \& Webb (1988) have also demonstrated that steroids alone are the major components involved in the negative feedback regulation of FSH and luteinizing hormone (LH) secretion in heifers, whereas in sheep a protein component of follicular fluid (presumably inhibin) is required for the full regulation of FSH concentrations (Martin et al., 1986, 1988). This questions whether an inhibin-induced FSH-mediated action of bFF is operative in intact heifers.

In addition, several studies using hypophysectomized ewes treated with pregnant mares' serum gonadotrophin (PMSG) have suggested that follicular fluid proteins may act at the level of the ovary to suppress follicular growth directly (Cahill, 1984; Cahill et al., 1985; Larson et al., 1987). In the light of these observations, we have investigated the importance of inhibin in the bFF-induced delay in return to oestrus after prostaglandin treatment in heifers. A preliminary report of these data has been presented elsewhere (Law et al., 1990).

\section{Materials and Methods}

\section{Protocol}

The animals used in the experiments were 2-year-old Hereford $\times$ Friesian heifers. All were housed indoors at the Large Animal Unit of the Institute of Animal Physiology and Genetics Research, Roslin and were kept together throughout the experiment. They were maintained on a diet of hay and concentrates and fresh water was available ad libitum. Oestrous activity was synchronized in all animals with two i.m. injections containing $500 \mu \mathrm{g}$ of a potent prostaglandin $F_{2 a}$ analogue, cloprostenol (Estrumate: ICI plc, Macclesfield, Cheshire) given 12 days apart. At the time of the second PG injection (day 0), the animals were assigned at random to the experimental groups for treatment.

In a dose-response experiment (Expt 1), 24 animals were assigned to one of four experimental groups and each received i.v. injections of either $10 \mathrm{ml}$ saline (control group, $n=6)$ or $2.5 \mathrm{ml}(n=6), 5 \mathrm{ml}(n=6)$ or $10 \mathrm{ml}(n=6)$ steroid-free $b F F$ every $8 \mathrm{~h}$ for 2 days, commencing at the time of the second prostaglandin injection.

In Expt 2, 18 animals were assigned to one of three experimental groups and each received i.v. injections of saline (control group, $n=6$ ), whole bFF (FF group, $n=6$ ) or bFF, the inhibin content of which had been greatly reduced (-INH group, $n=6$ ). As the material had been diluted during elution from the affinity column, each follicular fluid injection contained the protein equivalent of $20 \mathrm{ml}$ untreated follicular fluid, twice the dose found in Expt 1 to delay oestrus consistently, diluted to $40 \mathrm{ml}$ with saline. Control injections consisted of $40 \mathrm{ml}$ saline. Injections were administered every $8 \mathrm{~h}$ for 2 days, commencing at the time of the second prostaglandin injection. Blood samples were also taken every $8 \mathrm{~h}$ immediately before each injection, starting at the beginning of treatment and continuing for 11 days. Serum was stored at $-20^{\circ} \mathrm{C}$ to await assay. 
Animals were observed every $8 \mathrm{~h}$ for signs of oestrus; oestrus detection was aided by the use of a commercial heat detection device (Kamar Tags: Kamar Inc., Steamboat Springs, Colorado). In addition, during Expt 2, the ovaries of all animals were examined using real time ultrasonography on day 2 to examine the effects of treatment on the size of the largest follicle in an animal.

\section{Preparation of follicular fluid}

Follicular fluid was aspirated from all non-cystic follicles visible on bovine ovaries obtained from the local abattoir and stored frozen at $-20^{\circ} \mathrm{C}$ until required for further use. Since Tsonis et al. (1983) have shown that higher concentrations of charcoal remove inhibin-like activity, batches of bFF were pooled and treated with $1 \mathrm{mg}$ charcoal with $0.1 \mathrm{mg}$ Dextran per ml overnight at $4^{\circ} \mathrm{C}$ before centrifugation for $1 \mathrm{~h}$ at $2000 \mathrm{~g}$ to remove approximately $99 \%$ of steroids. The steroid-free bFF was then stored frozen in $25 \mathrm{ml}$ aliquots in readiness for affinity extraction.

\section{Immunoaffinity extraction of follicular fluid}

Mouse ascitic fluid antibody precipitated by ammonium sulfate was dissolved in 0.1 mol $\mathrm{NaHCO}_{3} 1^{-1} \mathrm{pH} 8 \cdot 5$, dialysed against $0 \cdot 1 \mathrm{~mol} \mathrm{NaHCO} \mathrm{I}^{-1}$ with at least six changes of dialysate, and coupled with an equal volume of an agarose gel (Affi-Gel 10; Bio-Rad, Sydney, Australia) according to the manufacturer's instructions. The gel was packed in a column $1.5 \mathrm{~cm}$ in diameter to about $7 \mathrm{~cm}$ depth. Inhibin was removed from bFF by affinity extraction using a monoclonal antibody to the $32 \mathrm{kDa}$ bovine inhibin $(256 \mathrm{H}$; Miyamoto et al., 1986). The extraction procedure was as follows. The column was equilibrated with a five times bed volume of $0.05 \mathrm{~mol}$ phosphate buffer $1^{-1} \mathrm{pH} 7.5$ containing $9 \mathrm{~g} \mathrm{NaCl1}^{-1}$ (PBS). Typically, $25 \mathrm{ml}$ bFF was loaded onto the column and washed through with PBS, and the protein-containing eluate was collected as inhibin-free bFF. The inhibin bound to the column was eluted with $0.1 \mathrm{~mol}$ glycine- $\mathrm{HCl}^{-1} \mathrm{pH} 2.0$ containing $0.01 \% \mathrm{PMSF}$ and was immediately neutralized with a one-fifth volume of 2 mol Tris- $\mathrm{HCl}^{-1} \mathrm{pH} 8 \cdot 5$. The column was rapidly neutralized with a twice gel volume of $0 \cdot 1 \mathrm{~mol} \mathrm{Tris-} \mathrm{HCl}^{-1} \mathrm{pH} \mathrm{9.0}$ and subsequently regenerated by washing with a three times gel volume of $6 \mathrm{~mol}$ guanidine- $\mathrm{HCl} 1^{-1}$ followed by re-equilibration with $0.1 \mathrm{~mol} \mathrm{Tris-} \mathrm{HCl}^{1}{ }^{1} \mathrm{pH} \mathrm{9.0}$. The column was then stored at $4^{\circ} \mathrm{C}$ overnight. These latter regeneration steps are important in maintaining the efficacy of the column.

Control bFF was processed through a similar immunoaffinity column to which a monoclonal antibody to chicken growth hormone (6F5; Goddard et al., 1987) had been coupled. This antibody has been extensively characterized and shown not to bind bovine growth hormone. Subsequent elution of this column with the $0 \cdot 1$ mol glycine- $\mathrm{HCl}^{-1}$ solution failed to elicit a protein peak.

\section{Electrophoresis and immunoblotting of the follicular fluid preparations}

Follicular fluid proteins were separated by SDS-PAGE under non-reducing conditions using a $10-15 \%$ gradient gel on the Phast-System (Pharmacia Ltd, Milton Keynes) according to the manufacturer's instructions (Technique File No. 110). Transfer of proteins onto nitrocellulose filters was performed using the Multiphor II system (Pharmacia). Blots were eluted for $90 \mathrm{~min}$ at $32 \mathrm{~mA}$ per blot using a Tris-glycine-methanol (pH 8.6) buffer system. Rainbow protein markers of low molecular mass (14-200 kDa; Amersham) were also run as standards. After transfer, the filters were blocked with 5\% (w/v) Marvel (Cadbury) in PBS (Blotto; $6 \times 5 \mathrm{~min}$ changes) and then incubated for $16 \mathrm{~h}$ with a specific antibody raised in rabbits against a synthetic 26 amino acid amino-terminus fragment of the $32 \mathrm{kDa}$ porcine $\alpha$-inhibin subunit (R150; McNeilly et al., 1989). The filters were further washed with Blotto as above and then incubated with a donkey anti-rabbit antibody conjugated to horse-radish peroxidase (SAPU, Carluke, Lanarkshire) for $2 \mathrm{~h}$ at room temperature. Blots were subsequently rewashed with Blotto, developed with chloro-1-naphthol $\left(3 \mathrm{mg} \mathrm{ml}^{-1}\right)$ in methanol and quenched in water.

\section{Hormone assays}

FSH was determined using the homologous double antibody radioimmunoassay system described by Bolt \& Rollins (1983). All samples were measured in a single assay. The sensitivity of the assay, taken to be the dose of hormone required to suppress the binding of labelled hormone significantly below that observed in zero standards was $0.75 \mathrm{ng}$ per tube $\left(3.00 \mathrm{ng} \mathrm{ml}^{-1}\right)$ and the within assay coefficient of variation calculated over the whole assay was $16.2 \%$.

LH was similarly determined using a conventional double antibody radioimmunoassay routinely used in this laboratory (Price \& Webb, 1988). All samples were measured in a single assay with a mean intra-assay coefficient of variation calculated over the whole assay of $11 \cdot 1 \%$.

Progesterone was assayed directly in a single assay, using a modification of the radioimmunoassay routinely used in this laboratory (Price \& Webb, 1988). Steroids were dissociated from plasma binding proteins by the inclusion of $100 \mathrm{ng} 8$-anilino-1-naphthalenesulfonic acid per assay tube. The crossreactivities of various steroids were as previously reported (Corrie $e t$ al., 1981) and progesterone added to plasma samples was recovered with a mean efficiency of $102 \%( \pm 1.38 \mathrm{SEM})$. The sensitivity of the assay was $7.8 \mathrm{pg}$ per tube $\left(0.16 \mathrm{ng} \mathrm{ml}^{-1}\right)$ and the within assay coefficient of variation was $13 \cdot 2 \%$. 
Oestradiol was assayed in pooled daily samples using the affinity extraction procedure described by Webb et al. (1985). All samples were assayed in a single assay with a mean extraction efficiency of $58.05 \pm 0.01 \%$. The sensitivity of the assay was $1.2 \mathrm{pg}$ per tube and the within assay coefficient of variation was $13.9 \%$.

Inhibin bioactivity was estimated by the ability of a sample to suppress basal FSH release from dispersed ovine pituitary cells in culture using the procedure of Tsonis et al. (1986), but with the addition of $10 \mathrm{ng} \mathrm{RU} 486 \mathrm{ml}^{-1}$ plus a highly specific oestradiol antisera (Land et al., 1982) at a dilution of 1:50000 to prevent any possible steroid interference. All media used in the cell culture procedure were obtained from Northumbria Biologicals Ltd. The lamb serum and donor bovine serum were obtained from Flow Laboratories, Rickmansworth, Hertfordshire. All samples, including the reference preparation, were stripped of steroids by incubation with $1 \mathrm{mg}$ charcoal $\mathrm{ml}^{-1}$ plus $0 \cdot 1 \mathrm{mg}$ dextran $\mathrm{ml}^{-1}$ overnight at $4^{\circ} \mathrm{C}$ and centrifugation for $1 \mathrm{~h}$ at $2000 \mathrm{~g}$, a process that removes approximately $99 \%$ of steroids (Wallace \& McNeilly, 1985). This was followed by passage down a Sep-Pak $\mathrm{C}_{18}$ cartridge (Waters Division, Millipore Corp.) which removed $>95 \%$ of the remaining steroids. All were subsequently sterilized by ultrafiltration through a $0.22 \mu \mathrm{m}$ filter $(\mu \mathrm{Star}$ : Costar Corporation, Cambridge, MA) and diluted as required in supplemented medium before inclusion in the assay.

Inhibin immunoactivity was determined as described previously (McNeilly et al., 1989). The samples were assayed in a single assay with an intra-assay coefficient of variation of $14 \cdot 2 \%$.

\section{Statistical analysis}

Unless stated otherwise, the data are presented as arithmetic means \pm SEM. Comparison of hormone profiles between groups was carried out by ANOVA, allowing for repeated measurements. Between-group comparisons of follicle diameter were performed using Student's $t$ test and time to return of oestrus was analysed by means of the Mann-Whitney-Wilcoxon test.

\section{Results}

\section{Experiment 1: dose-response study}

All control animals exhibited behavioural oestrus within 4 days of the second PG injection with a mean interval to oestrus of $75 \mathrm{~h}( \pm 7 \mathrm{~h}$; SEM). Oestrus was not significantly delayed $(P>0.05$ using both ANOVA and $\chi^{2}$ test) in animals treated with $2.5 \mathrm{ml}(113 \pm 28 \mathrm{~h}$; sEM) or $5 \mathrm{ml} \mathrm{bFF}$ $(139 \pm 22 \mathrm{~h} ;$ SEM $)$ per injection, although the delay in oestrus approached significance $(P=0.0547)$ in the higher dose group. Oestrus was uniformly and significantly $(P<0.005)$ delayed in all animals treated with $10 \mathrm{ml}$ bFF per injection (191 $\pm 6 \mathrm{~h}$; SEM).

\section{Experiment 2: effect of removal of inhibin}

Characterization of follicular fluid pools. Electrophoretic analysis of the fraction of bFF retained on the anti-inhibin column revealed the presence of multiple bands of staining differing in molecular mass (see Fig. 1). Western blots of the bFF fraction retained on the column (see Fig. 2), using a specific antibody raised against a portion of the inhibin $\alpha$ subunit (McNeilly et al., 1989) confirmed that the major band was inhibin of $32 \mathrm{kDa}$. Other bands corresponded to the multiple molecular mass species of inhibin initially described by Miyamoto et al. (1986), as well as to the 'free' monomeric $\alpha$ subunits known to be present in bFF (Knight et al., 1989; Robertson et al., 1989; Sugino et al., 1989). Adsorption of the first inhibin antibody with inhibin (porcine 1-26a) prevented binding, thus confirming the specificity. The inhibin bioassay demonstrated that the inhibin-free follicular fluid fraction, with a bioactivity of $560 \mathrm{iu} \mathrm{ml}^{-1}\left( \pm 75 \mathrm{iu} \mathrm{ml}^{-1}\right)$, contained less than $3 \%$ of the activity of a control follicular fluid pool $\left(22200 \pm 530 \mathrm{iu} \mathrm{ml}^{-1}\right)$. Immunoactive inhibin measurements confirmed that the inhibin activity in the bFF had been significantly reduced from

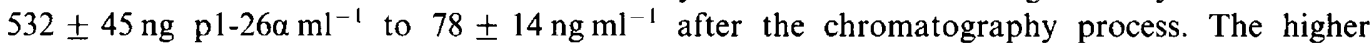
amount of immunoactive inhibin $(15 \%)$ compared with bioactive inhibin $(<3 \%)$ is presumably due to the interference of the 'free' inhibin $\alpha$-subunit in the radioimmunoassay.

Oestrus. All control animals exhibited behavioural oestrus within four days of the second PG injection with a mean interval to oestrus of $68 \mathrm{~h}( \pm 8 \mathrm{~h}$; SEM). Oestrus was uniformly and significantly $(P<0.001)$ delayed in both treatment groups to $186 \pm 5 \mathrm{~h}(\mathrm{FF}$ group; \pm SEM) and $191 \pm 6 \mathrm{~h}$ (-INH group; \pm SEM) after PG. There was no difference $(P>0.05)$ between the two treatment groups. 


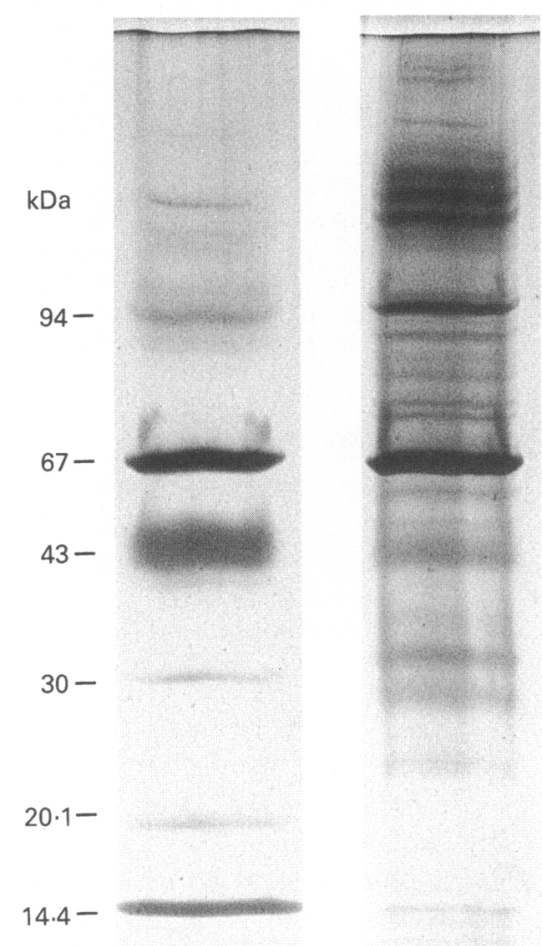

Fig. 1. Electrophoretic analysis of the fraction of bovine follicular fluid retained on the inhibin affinity column (lane 2). Molecular mass markers were run in lane 1 and the molecular masses of the individual markers are shown.

Follicle size. The mean diameter of the largest follicle on a pair of ovaries after one day of treatment was not significantly different $(P>0.05)$ between the two follicular fluid treatment groups $(7.5 \pm 0.4 \mathrm{~mm}$ versus $8.5 \pm 0.9 \mathrm{~mm}$; -INH versus FF groups), but the mean diameter of the largest follicle in the saline-treated control group of animals was significantly greater $(P<0.01)$ than that seen in the combined treatment groups $(11 \pm 0.9 \mathrm{~mm}$ versus $8.1 \pm 0.5 \mathrm{~mm}$; controls versus all treated animals).

Progesterone concentrations. Progesterone concentrations fell rapidly to below minimum detectable values in all animals after the second PG injection (Fig. 3a). A steady and sustained increase was observed in control animals, commencing on day 6 and continuing to the end of the sampling period. Progesterone remained below minimum detectable concentrations in all animals in both treatment groups. Samples taken from treated animals on day 16 revealed that progesterone concentrations had risen significantly above minimum detectable values by this time (data not shown).

Oestradiol concentrations. After PG injection at time 0 , oestradiol concentrations rose rapidly in control animals, reaching a peak at about the time of onset of oestrus in these animals (Fig. 3b). After oestrus, oestradiol fell rapidly to basal values and then subsequently rose to reach a second, smaller peak concentration at about day 8-9. In treated animals, oestradiol concentrations were initially suppressed below those seen in controls, but rose to a peak at about day 8-9, again coincident with the onset of oestrus in these animals. The amplitude of the pre-ovulatory peak of oestradiol in treated animals did not differ between treatments, but was significantly $(P<0.01)$ smaller than that seen in saline-treated controls. 


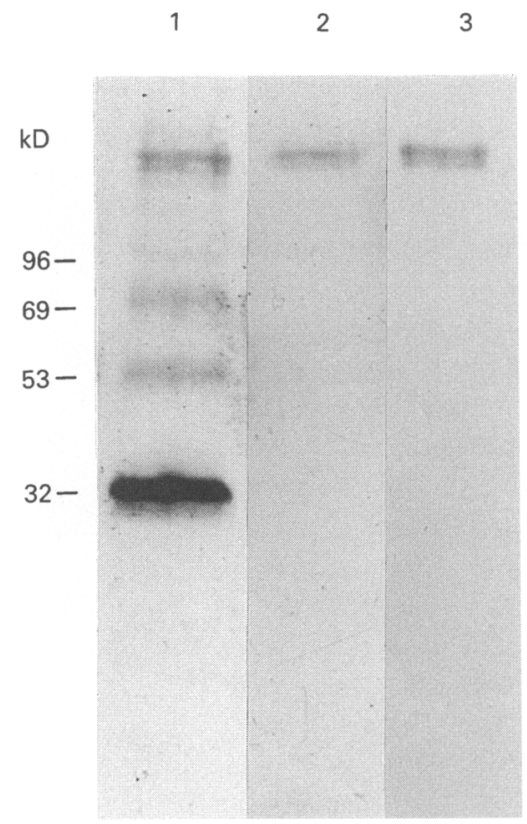

Fig. 2. SDS-PAGE/immunoblot of affinity purified inhibins from bovine follicular fluid. Lane 1: immunoblotted with rabbit anti-p1-26a inhibin; lane 2: immunoblotted with rabbit anti-p1$26 \alpha$ inhibin absorbed with p1-26a conjugate. Lane 3 : immunoblotted with donkey anti-rabbit horseradish peroxidase conjugate alone.

LH concentrations. Mean LH concentrations were initially high in all groups, but fell in control animals to values significantly lower $(P<0.01)$ than either treatment group by day 6 , remaining so for the remainder of the sampling period (Fig. 4).

FSH concentrations. FSH concentrations fell throughout the experimental period in all groups, including the controls (Fig. 5), but at no point during the treatment period were concentrations in treatment groups significantly different from those observed in control animals. After the cessation of injections, FSH concentrations increased in both experimental groups reaching values significantly higher than those in the respective treatment period $(P<0.01)$ and control values $(P<0.05)$. After this increase, FSH concentrations then returned to values similar to those seen in controls. There was no significant difference in FSH profiles between the -INH and the FF groups at any time during the experiment.

\section{Discussion}

These results demonstrate that treatment of heifers with steroid-free bFF delays the onset of oestrus following prostaglandin injection as previously reported (Miller et al., 1979; Johnson \& Smith, 1985; Quirk \& Fortune, 1986) but, importantly, that the delay in oestrus does not depend on the inhibin content of the follicular fluid. Furthermore, they also show that the delay in oestrus is not due to a failure of luteolysis, an observation previously confirmed in both cattle and sheep (Miller et al., 1979; Johnson \& Smith, 1985; Quirk \& Fortune, 1986). Rather it involves a suppression of follicular development, as evidenced by the peripheral oestradiol concentrations reported in this and previous reports (Johnson \& Smith, 1985; Quirk \& Fortune, 1986), and confirmed by the ultrasound data. A similar ultrasound-monitored suppression of follicular development by bFF at various times throughout the oestrous cycle has also been reported (Kastelic et al., 1990). 

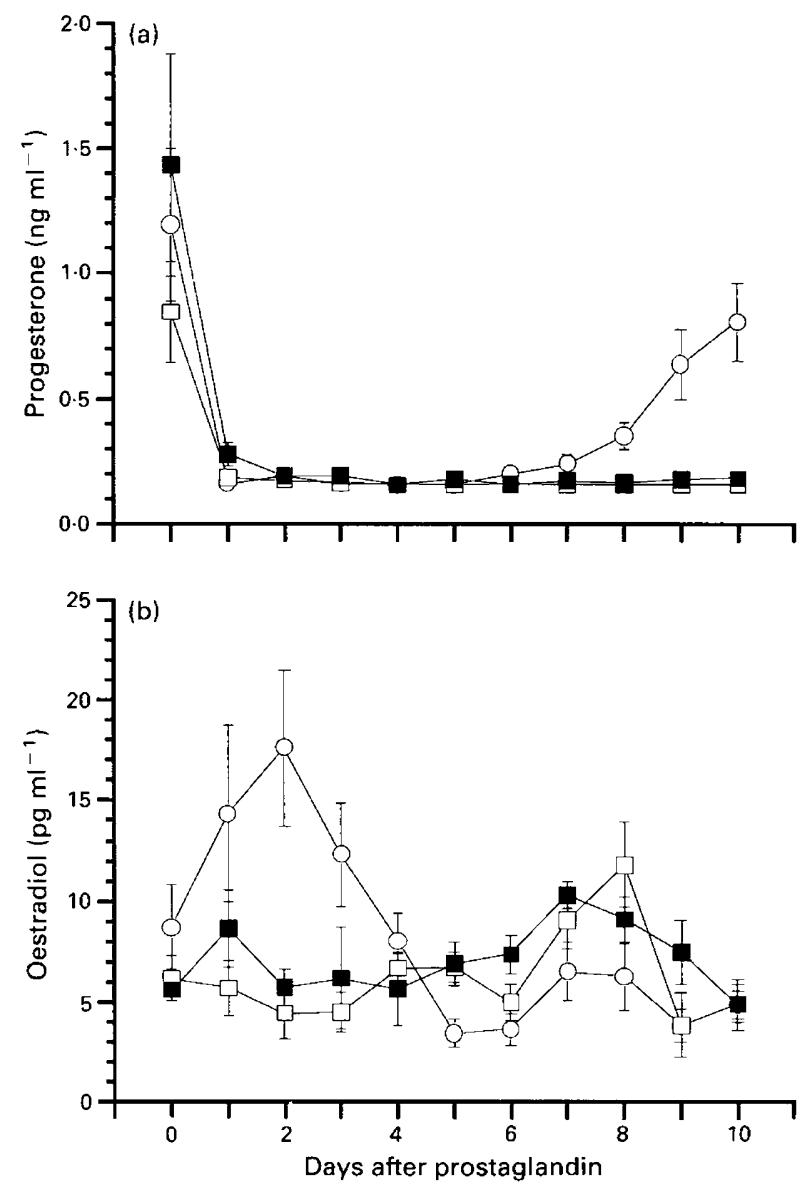

Fig. 3. (a) Mean daily progesterone concentrations and (b) mean daily oestradiol concentrationsin heifers treated with saline (control group, $O$ ), steroid-free bovine follicular fluid (FF group, $\square$ ) or steroid and inhibin-free bovine follicular fluid (-INH group, $\mathbf{\square})$ after prostaglandin injection.

It has been suggested that, in sheep, the bFF-induced suppression of follicular development is due to an inhibin-mediated suppression of FSH secretion (Miller et al., 1982; McNeilly, 1984; Wallace \& McNeilly, 1985, 1986; Henderson et al., 1986; Hunter et al., 1988). However, in the present study in intact cattle, no such suppression of FSH secretion was observed. In addition, there was no difference in response to treatment with either intact, or 'inhibin-free' follicular fluid. To our knowledge there is only one previous publication, using a smaller number of animals, reporting FSH concentrations following bFF treatment of intact adult cows at a similar stage of the oestrous cycle (Quirk \& Fortune, 1986). These authors claimed that the delay in oestrus was due to a reduction in FSH. However, FSH concentrations in treated animals were lower than those in controls before treatment started. Also in animals treated with $20 \mathrm{ml} \mathrm{bFF}$ for $24 \mathrm{~h}$ at $6 \mathrm{~h}$ intervals, a rebound of FSH appeared to have started before the last injection and without any preceding decrease in FSH. This apparent lack of effect of bFF treatment on circulating FSH concentrations is also supported by the finding that FSH can be maintained in the normal range in ovariectomized heifers with oestradiol and progesterone alone (Price \& Webb, 1988), unlike the case in sheep (Martin et al., 1988). Furthermore, it has been demonstrated that there is an inverse relationship between the amount of oestradiol and intact inhibin, as measured by a highly specific two-site immunoradiometric assay for dimeric inhibin, in follicular fluid (Beard et al., 1991). As most of the 

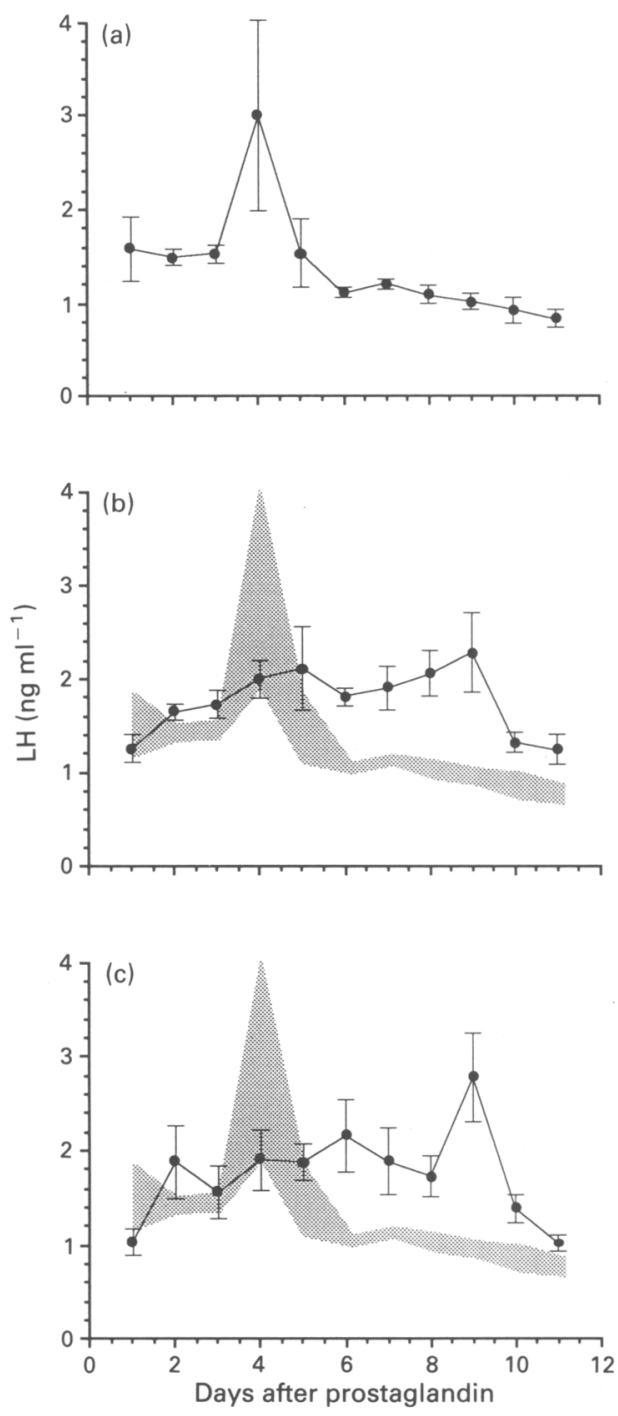

Fig. 4. Mean daily concentrations of luteinizing hormone (LH) in heifers treated with (a) saline (control group), (b) steroid-free bovine follicular fluid (FF group) or (c) steroid and inhibinfree bovine follicular fluid (-INH group) after prostaglandin injection at day 0 . The shaded area represents the mean \pm the standard deviation of the control group.

oestradiol emanates from the dominant follicle (Staigmiller et al., 1982), this questions further the role of inhibin in the control of FSH in intact adult females.

Follicular fluid contains at least one other protein with FSH-suppressing activity, namely follistatin (Robertson et al., 1987; Ueno et al., 1987). However, its potency is considerably less than that of inhibin (Robertson et al., 1990), and co-incubation with specific anti-inhibin antisera completely abolishes the FSH-suppressive action of bFF in ovine pituitary cell cultures (Muttukrishna \& Knight, 1990). Removal of the majority of the inhibin from follicular fluid would therefore be expected to remove the major part of any FSH-suppressing activity. The ability of the inhibin-free $\mathrm{bFF}$ to delay oestrus in this experiment would therefore suggest that the action of $\mathrm{bFF}$ in delaying oestrus is not related to its inhibin content. A recent report has also demonstrated that removal of 


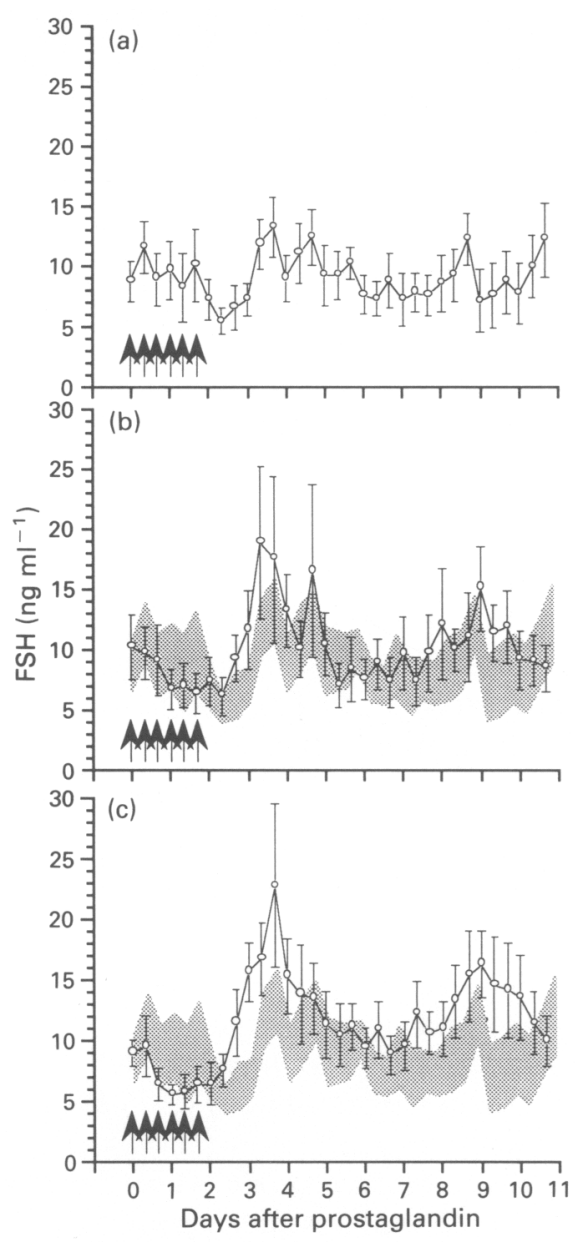

Fig. 5. Mean concentrations of follicle-stimulating hormone (FSH) in blood samples taken every eight hours from heifers treated with (a) saline (control group), (b) steroid-free bovine follicular fluid (FF group) or (c) steroid and inhibin-free bovine follicular fluid (-INH group) after prostaglandin injection on day 0 . The arrows indicate the timing of each follicular fluid or saline injection. The shaded area represents the mean \pm the standard deviation of the control group.

$92 \%$ of the inhibin activity from bFF does not reduce its ability to suppress follicular development and delay oestrus in sheep (Campbell et al., 1991). Immunoaffinity extraction of the bFF removed more than $95 \%$ of the inhibin in this study; the remaining activity was therefore equivalent to less than $1 \mathrm{ml}$ whole bFF inhibin per injection. Since $2.5 \mathrm{ml}$ of bFF in Expt 1 did not consistently delay oestrus, it is highly unlikely that the residual inhibin had any effect. In addition, Quirk \& Fortune (1986) have previously failed to delay oestrus in half their animals using a dose of $10 \mathrm{ml} b F F$ twice a day. Furthermore, bovine pituitary cells have been shown to be unresponsive to inhibin-containing preparations in vitro (Knight, 1991; A. S. Law \& R. Webb, unpublished observations). The weight of evidence therefore suggests that the principal action of bFF in delaying oestrus in cattle is not mediated either by inhibin or through a reduced pituitary secretion of FSH.

One possible alternative mechanism by which bFF treatment may inhibit follicular development is through a reduction in LH concentrations. The repeated injection of $\mathrm{LH}$ alone into 
anoestrous sheep is clearly sufficient to overcome the hormonal inadequacies in this experimental model (McNeilly et al., 1982), at least in breeds that have a shallow anoestrus, confirming that a reduced LH secretion can influence follicular development. However, mean daily $\mathrm{LH}$ concentrations were unaffected by follicular fluid treatment in either this or other experiments (Miller et al., 1982; Johnson \& Smith, 1985; Quirk \& Fortune, 1986). In addition, Picton et al. (1990) have demonstrated that basal LH is sufficient to support multiple follicular development in sheep. Furthermore, although pulsatile LH secretion was not measured in this study, other work has shown that LH pulse amplitude is actually increased by follicular fluid treatment (Wallace \& McNeilly, 1986; Law, 1991). A mode of action involving a suppression of LH release therefore seems unlikely. However, Picton et al. (1990) have reported that increased LH pulse amplitude is detrimental to follicular development; this observation warrants further investigation.

Given that treatment failed to alter the mean concentration of either gonadotrophin, it is worthy of note that oestradiol secretion was significantly suppressed in treated animals. This observation suggests that the principal effect of follicular fluid treatment, rather than being mediated via a reduction in gonadotrophin concentrations per se, may involve a reduction in follicular responsiveness to gonadotrophins. Indeed, evidence to support a direct ovarian action of bFF has already been documented in sheep; several groups using hypophysectomized ewes have demonstrated that bFF will suppress follicular development in the face of controlled PMSG treatment (Cahill, 1984; Cahill et al., 1985; Larson et al., 1987). Furthermore, Fry et al. (1987), using a similar model, have suggested that changes in gonadotrophin concentrations are not involved in the phenomenon of compensatory ovarian hypertrophy after unilateral ovariectomy. It would therefore appear that ovarian follicular proteins can act to suppress the development of other follicles in some manner independent of gonadotrophin concentrations.

The nature of the protein responsible for this action is uncertain. There are many proteins in follicular fluid, several of which have been characterized as having effects on the development and function of ovarian cells both in vivo and in vitro. The presence in bovine and porcine follicular fluid of a protein factor that was produced by the granulosa cells, and which prevented compensatory ovarian hypertrophy in mice has been described (Sato \& Ishibashi, 1977, 1978; Sato et al., 1978). Similarly the ovary containing the preovulatory follicle secretes a protein, follicle-regulatory protein (FRP; diZerega et al., 1982), which is produced by the granulosa cells (diZerega et al., 1983a; Tonetta et al., 1988) and which reduces the responsiveness of other follicles to gonadotrophins (diZerega et al., 1982, 1983b). Injection of porcine FRP suppressed follicular development in cyclic monkeys (diZerega \& Wilks, 1984) and guinea-pigs (Fujimori et al., 1987). Other authors have also reported that porcine and bovine follicular fluid contain several factors that inhibit the binding of FSH to its receptor (Sluss et al., 1983, 1987, 1989; Sluss \& Reichert, 1984a), although this activity may be the result of bacterial action (Sluss \& Reichert, 1984b). Of particular note is the observation that the precursors of the $\alpha$-inhibin molecule influence FSH binding and activity in vitro (Schneyer et al., 1991), given that the inhibin-free bFF in this study was shown to contain some residual free $\alpha$-inhibin subunit immunoactivity. Any one or more of these follicular fluid components may be responsible for the observed effects of bFF treatment. The exact nature of the active principle awaits further research.

Of additional interest is the observation of a 'rebound' increase in the secretion of FSH despite the absence of any prior suppression, in agreement with the findings of Johnson \& Smith (1985). The similarity of the rebound between intact and inhibin-stripped bFF-treated groups suggests that the rebound is not due to an action of inhibin. Campbell et al. (1991) have also confirmed that this rebound of FSH is not mediated by inhibin in sheep. The timing of the $\mathrm{FSH}$ rebound in relation to the cessation of treatment suggests that another bFF protein, rather than inhibin, is involved in the negative feedback regulation of FSH. The maintenance of FSH concentrations in the face of reduced ovarian oestradiol production during the treatment period would further suggest that the action of the putative bFF factor is to increase the sensitivity of the pituitary gland to steroid negative feedback. These observations also warrant further investigation. 
Waves of follicles develop regularly throughout the oestrous cycle (Sirois \& Fortune, 1988; Savio et al., 1988, 1990), but only the dominant follicle of the final wave ovulates. The process of ovulation presumably removes the factors responsible for the dominance of the ovulatory follicle and allows the initiation of the first non-ovulatory wave. The cessation of bFF treatment in this study was approximately coincident with the timing of oestrus and ovulation in the saline-treated control animals. The coincidental rise in oestradiol secretion in all groups from days 5 to 6 may therefore reflect a similar withdrawal of follicular suppression in all groups, suggesting that the factor(s) responsible for bFF-induced suppression of follicular development and follicular dominance are the same.

Interestingly, the size of the preovulatory peak of oestradiol was lower in both bFF-treated groups than in saline-treated controls. However, it was clearly sufficient to elicit oestrous behaviour and trigger the endocrine events leading to luteinization. The reasons for this reduced oestradiol secretion are not immediately apparent. Possibly the prolonged 'follicular phase' caused by the bFF treatment following the fall in progesterone at luteolysis resulted in an increase in the sensitivity of the hypothalamus/pituitary gland to oestradiol, and hence a premature initiation of the gonadotrophin surge, thus preventing the normal rise in oestradiol concentrations. Progesterone treatment has previously been demonstrated to delay the onset of the preovulatory gonadotrophin surge in GnRH-treated anoestrous ewes (McLeod et al., 1982). Alternatively, the reduced oestradiol secretion may be due to a direct action of the prior bFF treatment on the developing follicle. The dominant follicle of the primate ovarian cycle exerts effects on non-dominant follicles that remain even after ablation of the dominant follicle (diZerega \& Hodgen, 1980). Possibly such effects remained following bFF treatment in this study.

In conclusion, the action of bFF in suppressing follicular development is a direct effect, and is not mediated via reduced FSH concentrations. The activity is not related to the inhibin content of follicular fluid. Furthermore, the hypersecretion of FSH observed following bFF treatment is likewise not due to inhibin, and is not dependent on a prior suppression of FSH. The patterns of oestradiol and FSH concentrations in relation to the timing of the bFF treatment suggest a potentiating effect of non-inhibin bFF proteins on the negative feedback effects of oestradiol. These results further suggest that the mechanism of follicular dominance does not involve a selective reduction in FSH concentrations.

We wish to thank the staff of the Large Animal Unit for assistance with animal handling, blood sampling and oestrus detection, D. McBride and C. Warren for expert technical assistance, A. Springbett for help with the statistical analyses, K. Miyamoto and C. Goddard for the gifts of monoclonal antibodies, and D. Bolt of the USDA for reagents used in the assays.

This work was funded by MAFF and A. S. Law was in receipt of an AFRC postgraduate studentship.

\section{References}

Beard, A.J., Groome, N. \& Knight, P.G. (1991) Estimation of immunoreactive (ir) inhibin concentrations in bovine ovarian follicles using a novel 2-site immunoradiometric assay (IRMA) specific for dimeric inhibin. Journal of Reproduction and Fertility Abstract Series 7, Abstract 40.

Bolt, D.J. \& Rollins, R. (1983) Development and application of a radioimmunoassay for bovine folliclestimulating hormone. Journal of Animal Science 56, 146-154.

Cahill, L.P. (1984) Folliculogenesis and ovulation rate in sheep. In Reproduction in Sheep, pp. 92-98. Eds D. R. Lindsay \& D. T. Pearce. Cambridge University Press, Cambridge.
Cahill, L.P., Driancourt, M-A., Chamley, W.A. \& Findlay, J.K. (1985) Role of intrafollicular regulators and FSH in growth and development of large antral follicles in sheep. Journal of Reproduction and Fertility 75, 599-607.

Campbell, B.K., Picton, H.M., Mann, G.E., McNeilly, A.S. \& Baird, D.T. (1991) Effect of steroid-and inhibin-free ovine follicular fluid on ovarian follicles and ovarian hormone secretion. Journal of Reproduction and Fertility 93, 81-96.

Corrie, J.T., Hunter, W.M. \& Macpherson, J.S. (1981) A strategy for radioimmunoassay of plasma progesterone with the use of a homologous site ${ }^{125} \mathrm{I}$-labelled radioligand. Clinical Chemistry 27, 594-599. 
diZerega, G.S. \& Hodgen, G.D. (1980) The primate ovarian cycle: suppression of human menopausal gonadotropin-induced follicular growth in the presence of the dominant follicle. Journal of Clinical Endocrinology and Metabolism 50, 819-825.

diZerega, G.S. \& Wilks, J.W. (1984) Inhibition of the primate ovarian cycle by a porcine follicular fluid protein(s). Fertility and Sterility 41, 635-638.

diZerega, G.S., Goebelsmann, U. \& Nakamura, R.M. (1982) Identification of protein(s) secreted by the preovulatory ovary which suppresses the follicle response to gonadotropins. Journal of Clinical Endocrinology and Metabolism 54, 1091-1096.

diZerega, G.S., Marrs, R.P., Campeau, J.D. \& Kling, O.R. (1983a) Human granulosa cell secretion of protein(s) which suppress follicular response to gonadotropins. Journal of Clinical Endocrinology and Metabolism 56, 147-155.

diZerega, G.S., Marrs, R.P., Roche, P.C., Campeau, J.D. \& Kling, O.R. (I983b) Identification of proteins in pooled human follicular fluid which suppress follicular response to gonadotropins. Journal of Clinical Endocrinology and Metabolism 56, 35-41.

Fry, R.C., Clarke, I.J. \& Cahill, L.P. (1987) Changes in gonadotrophin concentrations are not necessarily involved in ovarian compensation after unilateral ovariectomy in sheep. Journal of Reproduction and Fertility 79, 45-48.

Fujimori, K., Nakamura, R.M., Tonetta, S.A. \& diZerega, G.S. (1987) Cessation of transition-phase follicle growth in the guinea pig by follicle-regulatory protein. Biology of Reproduction 37, 812-822.

Goddard, C., Houston, B. \& Gray, C. (1987) Monoclonal antibody to chicken growth hormone. Journal of Endocrinology 112 (Supplement), Abstract 125.

Henderson, K.M., Prisk, M.D., Hudson, N., Ball, K., McNatty, K.P., Lun, S., Heath, D.A., Kieboom, L.E. \& McDiarmid, J. (1986) Use of bovine follicular fluid to increase ovulation rate or prevent ovulation in sheep. Journal of Reproduction and Fertility 76, 623-635.

Hunter, M.G., Hindle, J.E., McLeod, B.J. \& McNeilly, A.S. (1988) Treatment with bovine follicular fluid suppresses follicular development in gonadotrophinreleasing hormone treated anoestrous ewes. Journal of Endocrinology 119, 95-100.

Johnson, S.K. \& Smith, M.F. (1985) Effect of charcoalextracted, bovine follicular fluid on gonadotropin concentrations, the onset of estrus and luteal function in heifers. Journal of Animal Science 61, 203-209.

Kastelic, J.P., Ko, J.C.H. \& Ginther, O.J. (1990) Suppression of dominant and subordinate ovarian follicles by a proteinaceous fraction of follicular fluid in heifers. Theriogenology 34, 499-509.

Knight, P.G. (1991) Identification and purification of inhibin and inhibin-related proteins. Journal of Reproduction and Fertility Supplement 43, 111-123.

Knight, P.G., Beard, A.J., Wrathall, J.H.M. \& Castillo, R.J. (1989) Evidence that the bovine ovary secretes large amounts of monomeric inhibin $\alpha$ subunit and its isolation from bovine follicular fluid. Journal of Molecular Endocrinology 2, 189-200.

Land, R.B., Morris, B.A., Baxter, G., Fordyce, M. \& Forster, J. (1982) Improvement of sheep fecundity by treatment with antisera to gonadal steroids. Journal of Reproduction and Fertility 66, 625-634.
Larson, G.H., Mallory, D.S., Lewis, P.E., Dailey, R.A. \& Inskeep, E.K. (1987) Effect of bovine follicular fluid (BFF) on follicular development following pituitary stalk-transection in ewes. Journal of Animal Science 65, (Supplement 1), Abstract 440.

Law, A.S. (1991) The Role of Follicular Fluid Proteins in the Control of Gonadotrophin Secretion and Follicular Development in the Heifer. PhD Thesis, University of Edinburgh.

Law, A.S., Logue, D.N., O'Shea, T. \& Webb, R. (1990) Evidence for a novel factor in steroid-free bovine follicular fluid (bFF) which acts to directly suppress follicular development. Journal of Reproduction and Fertility Abstract Series 5, Abstract 4.

McLeod, B.J., Haresign, W. \& Lamming, G.E. (1982) Response to seasonally anoestrous ewes to smalldose multiple injections of GnRH with and without progesterone pretreatment. Journal of Reproduction and Fertility 65, 223-230.

McNeilly, A.S. (1984) Changes in FSH and the pulsatile secretion of LH during the delay in oestrus induced by treatment of ewes with bovine follicular fluid. Journal of Reproduction and Fertility 72, 165-172.

McNeilly, A.S. (1985) Effects of changes in FSH induced by bovine follicular fluid and FSH infusion in the preovulatory phase on subsequent ovulation rate and corpus luteum function in the ewe. Journal of Reproduction and Fertility 74, 661-668.

McNeilly, A.S., O'Connell, M. \& Baird, D.T. (1982) Induction of ovulation and normal luteal function by pulsed injections of luteinizing hormone in anestrus ewes. Endocrinology 110, 1292-1299.

McNeilly, A.S., Swanston, I.A., Crow, W., Tsonis, C. \& Baird, D.T. (1989) Changes in the plasma concentrations of inhibin throughout the normal sheep oestrous cycle and after the infusion of FSH. Journal of Endocrinology 120, 295-305.

Martin, G.B., Wallace, J.M., Taylor, P.L., Fraser, H.M., Tsonis, C.G. \& McNeilly, A.S. (1986) The role of inhibin and gonadotrophin-releasing hormone in the control of gonadotrophin secretion in the ewe. Journal of Endocrinology 111, 287-296.

Martin, G.B., Price, C.A., Thiéry, J-C. \& Webb, R. (1988) Interactions between inhibin, oestradiol and progesterone in the control of gonadotrophin secretion in the ewe. Journal of Reproduction and Fertility 82, 319-328.

Miller, K.F., Critser, J.K., Rowe, R.F. \& Ginther, O.J. (1979) Ovarian effects of bovine follicular fluid treatment in sheep and cattle. Biology of Reproduction 21, 537-544.

Miller, K.F.,Critser, J.K. \& Ginther, O.J. (1982) Inhibition and subsequent rebound of FSH secretion following treatment with bovine follicular fluid in the ewe. Theriogenology 18, 45-53.

Miyamoto, K., Hasegawa, Y., Fukada, M. \& Igarashi, M. (1986) Demonstration of high molecular weight forms of inhibin in bovine follicular fluid (bFF) by using monoclonal antibodies to bFF $32 \mathrm{~K}$ inhibin. Biochemical and Biophysical Research Communications 136, 1103-1109.

Muttukrishna, S. \& Knight, P.G. (1990) Effects of crude and highly purified bovine inhibin $\left(M_{\mathrm{r}} 32000\right.$ form) on gonadotrophin production by ovine pituitary cells in vitro. Journal of Endocrinology 127, 149-159. 
Picton, H.M., Tsonis, C.G. \& McNeilly, A.S. (1990) The antagonistic effect of exogenous LH pulses on FSHstimulated preovulatory follicle growth in ewes chronically treated with a gonadotrophin-releasing hormone agonist. Journal of Endocrinology 127, 273-283.

Price, C.A. \& Webb, R. (1988) Steroid control of gonadotropin secretion and ovarian function in heifers. Endocrinology 122, 2222-2231.

Quirk, S.M. \& Fortune, J.E. (1986) Plasma concentrations of gonadotrophins, preovulatory follicular development and luteal function associated with bovine follicular fluid-induced delay of oestrus in heifers. Journal of Reproduction and Fertility 76, 609-621.

Robertson, D.M., Klein, R., de Vos, F.L., McLachlan, R.I., Wettenhall, R.E.H., Hearn, M.T.W., Burger, H.G. \& de Kretser, D.M. (1987) The isolation of polypeptides with FSH suppressing activity from bovine follicular fluid which are structurally different to inhibin. Biochemical and Biophysical Research Communications 149, 744-749.

Robertson, D.M., Giacometti, M., Foulds, L.M., Lahnstein, J., Goss, N.H., Hearn, M.T.W. \& de Kretser, D.M. (1989) Isolation of inhibin $\alpha$-subunit precursor proteins from bovine follicular fluid. Endocrinology 125, 2141-2149.

Robertson, D.M., Farnworth, P.G., Clarke, L., Jacobsen, J., Cahir, N.F., Burger, H.G. \& de Kretser, D.M. (1990) Effects of bovine $35 \mathrm{kDa}$ FSH-suppressing protein on FSH and LH in rat pituitary cells in vitro: comparison with bovine $31 \mathrm{kDa}$ inhibin. Journal of Endocrinology 124, 417-423.

Sato, E. \& Ishibashi, T. (1977) Inhibition of compensatory ovarian hypertrophy in the mouse by the administration of the non-dialysable fraction of bovine follicular fluid. Japanese Journal of Zootechnical Science 48, 782-783.

Sato, E. \& Ishibashi, T. (1978) Partial purification of the gonadotropin inhibiting substance found in bovine follicular fluid. Japanese Journal of Zootechnical Science 49, 313-318.

Sato, E., Miyamoto, H., Ishibashi, T. \& Iritani, A. (1978) Identification, purification and immunohistochemical detection of the inhibitor from porcine follicular fluid to compensatory ovarian hypertrophy in mice. Journal of Reproduction and Fertility 54, 263-267.

Savio, J.D., Keenan, L., Boland, M.P. \& Roche, J.F. (1988) Pattern of growth of dominant follicles during the oestrous cycle of heifers. Journal of Reproduction and Fertility 83, 663-671.

Savio, J.D., Boland, M.P. \& Roche, J.F. (1990) Development of dominant follicles and length of ovarian cycles in post-partum dairy cows. Journal of Reproduction and Fertility 88, 581-591.

Schneyer, A.L., Sluss, P.M., Whitcomb, R.W., Martin, K.A., Sprengel, R. \& Crowley, W.F. (1991) Precursors of $\alpha$-inhibin modulate follicle-stimulating hormone receptor binding and biological activity. Endocrinology 129, 1987-1999.

Sirois, J. \& Fortune, J.E. (1988) Ovarian follicular dynamics during the estrous cycle in heifers monitored by real-time ultrasonography. Biology of Reproduction 39, 308-317.
Sluss, P.M. \& Reichert, L.E. (1984a) Porcine follicular fluid contains several low molecular weight inhibitors of follicle-stimulating hormone binding to receptor. Biology of Reproduction 30, 1091-1 104.

Sluss, P.M. \& Reichert, L.E. (1984b) Secretion of an inhibitor of follicle stimulating hormone binding to receptor by the bacteria Serratia, including a strain isolated from porcine follicular fluid. Biology of Reproduction 31, 520-530.

Sluss, P.M., Fletcher, P.W. \& Reichert, L.E. (1983) Inhibition of ${ }^{125}$ I-human follicle-stimulating hormone binding to receptor by a low molecular weight fraction of bovine follicular fluid: inhibitor concentration is related to biochemical parameters of follicular development. Biology of Reproduction 29, 1105-1113.

Sluss, P.M., Schneyer, A.L., Franke, M.A. \& Reichert, L.E. (1987) Porcine follicular fluid contains both follicle-stimulating hormone agonist and antagonist activities. Endocrinology 120, 1477-1481.

Sluss, P.M., Branca, A.A., Ford, J.J., Krishnan, K.A. \& Reichert, L.E. (1989) Purification, measurement, and tissue distribution of a dansyl-derivatized glycopeptide from low-molecular weight folliclesimulating hormone-inhibitor-containing fractions of porcine follicular fluid. Biology of Reproduction 40, 407-415.

Staigmiller, R.B., England, B.G., Webb, R., Short, R.E. \& Bellows, R.A. (1982) Estrogen secretion and gonadotropin binding by individual bovine follicles during estrus. Journal of Animal Science 55, 1473-1482.

Sugino, K., Nakamura, T., Takio, K., Titani, K., Miyamoto, K., Hasegawa, Y., Igarashi, M. \& Sugino, H. (1989) Inhibin alpha-subunit monomer is present in bovine follicular fluid. Biochemical and Biophysical Research Communications 159, 1323-1329.

Tonetta, S.A., Yanagihara, D.L., DeVinna, R.S. \& diZerega, G.S. (1988) Secretion of follicle-regulatory protein by porcine granulosa cells. Biology of Reproduction 38, 1001-1005.

Tsonis, C.G., Quigg, H., Lee, V.W.K., Leversha, L., Trounson, A.O. \& Findlay, J.K. (1983) Inhibin in individual follicles in relation to diameter and atresia. Journal of Reproduction and Fertility 67, 83-90.

Tsonis, C.G., McNeilly, A.S. \& Baird, D.T. (1986) Measurement of exogenous and endogenous inhibin in sheep serum using a new and extremely sensitive bioassay for inhibin based on inhibition of ovine pituitary FSH secretion in vitro. Journal of Endocrinology 110, 341-352.

Ueno, N., Ling, N., Ying, S-Y., Esch, F., Shimasaki, S. \& Guillemin, R. (1987) Isolation and partial characterization of follistatin: a single-chain $M_{\mathrm{r}} 35000$ monomeric protein that inhibits the release of folliclestimulating hormone. Proceedings of the National Academy of Sciences, USA 84, 8282-8286.

Wallace, J.M. \& McNeilly, A.S. (1985) Increase in ovulation rate after treatment of ewes with bovine follicular fluid in the luteal phase of the oestrouscycle. Journal of Reproduction and Fertility 73, 505-515.

Wallace, J.M. \& McNeilly, A.S. (1986) Changes in FSH and the pulsatile secretion of $\mathrm{LH}$ during treatment of ewes with bovine follicular fluid throughout the luteal phase of the oestrous cycle. Journal of Endocrinology 111, 317-327. 
Webb, R., Baxter, G., McBride, D., Nordblom, G.D. \& Shaw, M.P.K. (1985) The measurement of testosterone and oestradiol-17 $\beta$ using iodinated tracers and incorporating an affinity chromatography extraction procedure. Journal of Steroid Biochemistry 23, 1043-1051.

Received 7 October 1991 